\title{
Suitability of Tyre Derived Geomaterial Mixed with Gravel to be used in Gabion Type Retaining Wall
}

\author{
Amizatulhani Abdullah, Mohd Yuhyi Mohd Tadza
}

\begin{abstract}
The disposal of scrap tyre is a major problem in developing countries. Material recycling is adopted in order to promote safer disposal (beside conventional dump and thermal recycling). Tyre derived geomaterial (TDGM) are proposed to be used in construction of gabion type retaining wall to prevent slope failure that has been a serious geotechnical threat in many countries. The reason of choosing tyre is not only to help in reducing the stockpiling of scrap tyre generated in environmental friendly way but also to reduce the dependency of gravel as the material to filled current gabion wall. In this study, laboratory scale model of gabion wall was developed to protect soil slope. Various proportion mixture of gravel:TDGM were used to construct the gabion wall. The protected slope was subjected to an artificial rainfall of $13 \mathrm{~mm} / \mathrm{hour}$. Soil movement from commencement of the test until the slope failed was recorded by using transducers. Sieve analysis, specific gravity test and compaction test were conducted beforehand upon all materials used in the study to determine basic characteristics of the materials. From this study, it is found that, due to its lightweight properties, the use of TDGM (tyre chips and tyre buffer) as unique material in gabion wall was insufficient to reduce the displacement of the gabion wall. Larger displacement of gabion wall was recorded in the case of gravel:TDGM mixture was used to fill gabion wall. TDGM need to be mixed with large amount of gravel (at least $80 \%$ by volume) to increase the self-weight of the gabion wall and increase its stability.
\end{abstract}

Keywords : Gabion wall, gravel replacement, laboratory model, slope stability, tyre derived geomaterial

\section{INTRODUCTION}

The generation of scrap tyres and its disposal is a major problem, especially in developing countries. The conventional open dumping method will lead to the easily spread of diseases as well as it creates an unpleasant view. In developed countries, thermal recycling of scrap tyres has been practiced to reduce the amount of scrap tyres generated each year. However, thermal recycling also can cause a problem from the environment point of view because it contributes to the carbon dioxide generation. On that account, material recycling which is more environmental friendly way of waste utilization was explored.

Revised Manuscript Received on October 22, 2019.

* Correspondence Author

Amizatulhani Abdullah*, Faculty of Civil Engineering Technology, Universiti Malaysia Pahang, Gambang, Kuantan, Pahang, Malaysia. Email: amizatulhani@ump.edu.my

Mohd Yuhyi Mohd Tadza, Faculty of Civil Engineering Technology, Universiti Malaysia Pahang, Gambang, Kuantan, Pahang, Malaysia. Email: dryuhyi@ump.edu.my
In the past few years, studies regarding the utilization of tyres in construction projects have gained popularity. These studies include laboratory testing, numerical simulation, and physical modelling as well as field investigation. Due to its advantageous physical and mechanical characteristics, tyre derived geomaterial (TDGM) either in the form of shreds, chips or crumbs has been used as filler material for embankments [1], as backfill material behind retaining walls and abutments [2]-[3], as base isolation for buildings [4] and as lining in tunnelling works [5]. The effectiveness of TDGM to mitigate soil's liquefaction behind retaining wall and under shallow foundation have also been studied [6]-[11]. In addition, research on the potential of TDGM has also covered wide range of waste tyre utilization, either as a whole (i.e. uncut) in conjunction with granular materials [12] or being cut into pieces [13]-[16]. The results of these studies showed improvement in soil characteristics and engineering behaviors when TDGM were utilized on temporary or permanent soil structures as full or partial substitute material.

On the other hand, slope failure is a worldwide geotechnical hazard that can caused losses of lives and damages of structures and infrastructures. Huge amount of money was needed to restore all the damages due to slope failure. Slope failure occurred when slope collapses abruptly due to weakened self-retainability of the soil under the influence of a prolonged rainfall or earthquake. Preventive measures were often taken to prevent slopes from failure. One of the most common method is by constructing retaining wall (i.e. gabion wall) at the toe of the slope. A gabion wall is a retaining wall which made of stacked stone-filled gabions placed within a wire mesh. Gabion walls are usually angled back towards the slope, or stepped back with the slope, rather than stacked vertically. It has been used widely to protect soil slopes along roads and highways especially in Malaysia. Fig. 1 shows a typical type of gabion wall that normally been used in Malaysia.

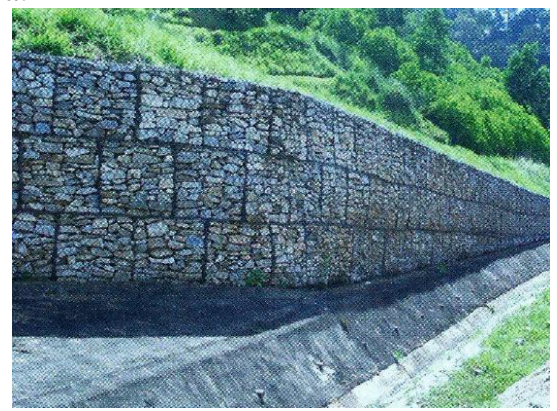

Fig 1. Typical type of gabion wall [17] 


\section{METHODOLOGY}

\section{A. Preparation of materials}

Gravel and sand used in this study were locally obtained from Kuantan area while tyres are purchased from a tyre retread company in Kuantan, Pahang. Fig. 2(a) shows picture of gravel, tyre chips, soil and tyre buffer used in this study while, Fig. 2(b) shows the sample of tyre buffer. All the materials were tested for its basic properties as shown in Table I.

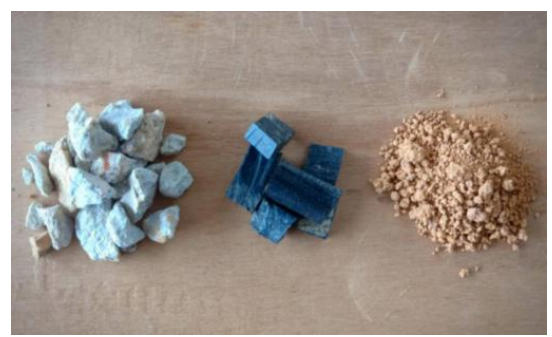

(a)

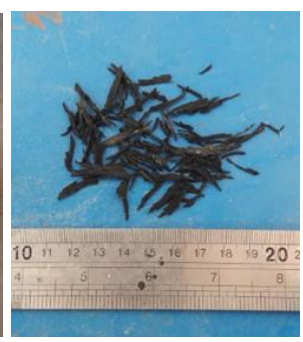

(b)
Fig 2. (a) Gravel, tyre chips and soil, (b) Tyre buffer

Table I: Laboratory testing to determine basic properties of the materials

\begin{tabular}{|c|c|}
\hline Laboratory test & Standard \\
\hline Sieve analysis & ASTM D422 \\
\hline Specific gravity (soil) & ASTM D854 \\
Specific gravity (gravel) & ASTM C127-15 \\
\hline Compaction & ASTM D698 \\
\hline
\end{tabular}

\section{B. Development of Slope Model}

There are five types of slope model that have been developed in this study. Table 2 shows the description for the five types of the slope model. The unprotected soil slope model (Model 1), was constructed by using three different angle $\left(30^{\circ}, 45^{\circ}\right.$ and $\left.60^{\circ}\right)$. While, the protected soil slope models (Model 2, Model 3, Model 4 and Model 5), were constructed by using the most critical angle obtained in Model 1. Fig. 3 shows the general layout of protected slope model by using gabion wall.

All the slope models were made in clear acrylic box. A marking line was drawn outside the acrylic box as the guidance in constructing the slope. Dry soil was poured into the box at a constant height of approximately $30 \mathrm{~cm}$ to ensure that the density of the sand was almost the same for all the slope models. Sand were poured until it reached the marking line drawn. Several cages of gabion wall were lined up along the slope's toe. The arrangement was made according to the guideline given by the Public Works Department Malaysia.

Table II: Types of the slope model

\begin{tabular}{|c|c|c|}
\hline Model & Types of slope & Material used to made gabion wall \\
\hline 1 & $\begin{array}{c}\text { Unprotected } \\
\text { soil slope }\end{array}$ & - \\
\hline 2 & \multirow{4}{*}{$\begin{array}{l}\text { Protected soil } \\
\text { slope by using } \\
\text { gabion wall }\end{array}$} & Gravel \\
\hline 3 & & Tyre buffer \\
\hline 4 & & $\begin{array}{c}\text { Gravel and tyre chips } \\
\text { (proportion mixture by volume of } 80: 20 \text {, } \\
50: 50 \text { ) }\end{array}$ \\
\hline 5 & & $\begin{array}{c}\text { Gravel and tyre buffer } \\
\text { (proportion mixture by volume of } 80: 20 \text {, } \\
50: 50,20: 80 \text { ) }\end{array}$ \\
\hline
\end{tabular}

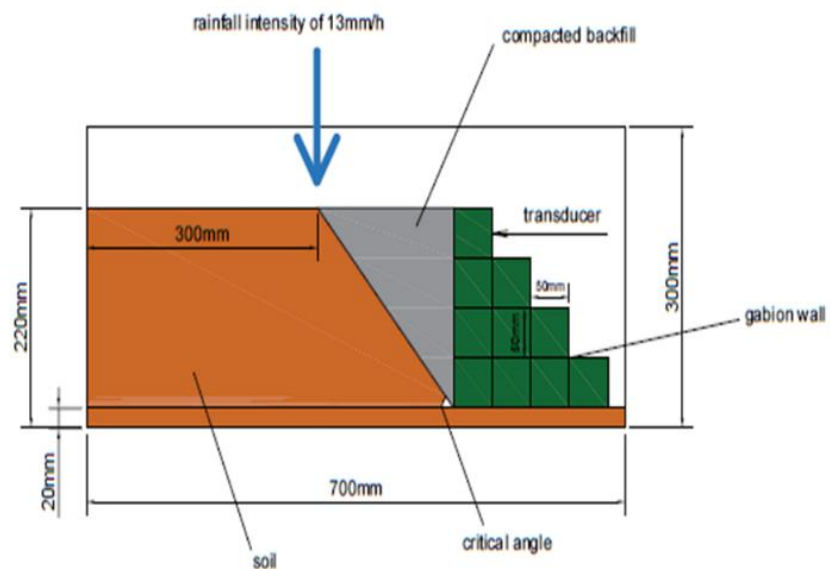

Fig 3. General layout of protected slope model by using gabion wall

\section{Execution of Rainfall Test}

The completed slope model was placed on top of hydrology and rainfall apparatus which can be found in Hydraulic and Hydrology Laboratory of Universiti Malaysia Pahang. This apparatus consists of a metal frame which holds spray nozzles that can simulate rainfall. Source of water are coming from the reservoir attached under the apparatus. Water was pumped from the reservoir to the overhead nozzles. The amount of water that came out from the nozzle can be controlled by using flow valve which located at the middle of the apparatus.

In this study, the rainfall rate of $13 \mathrm{~mm} /$ hour was selected based on the average value of rainfall experienced in Kuantan for the year 2017 and 2018. The data was taken from Drainage and Irrigation Department of Malaysia. In this study, the rainfall was subjected to all the slope models by using the hydrology and rainfall apparatus as described previously. The hydrology apparatus that used in this study is shown in Fig. 4. All models were subjected to an artificial rainfall at a constant rate until the slope fails.

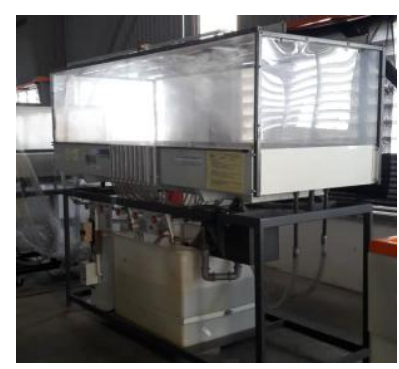

Fig 4. Hydrology apparatus

\section{RESULTS AND DISCUSSION}

\section{A. Material properties}

Particle size distribution test has been conducted to all materials used in this study. The particle size distribution plot of the soil, gravel and TDGM used in this study is shown in Fig. 5. Meanwhile, the size of tyre chips was set to be in standard size of $20 \mathrm{~mm}$. Table III shows the results of specific gravity test and compaction test conducted upon all materials used in the study. 


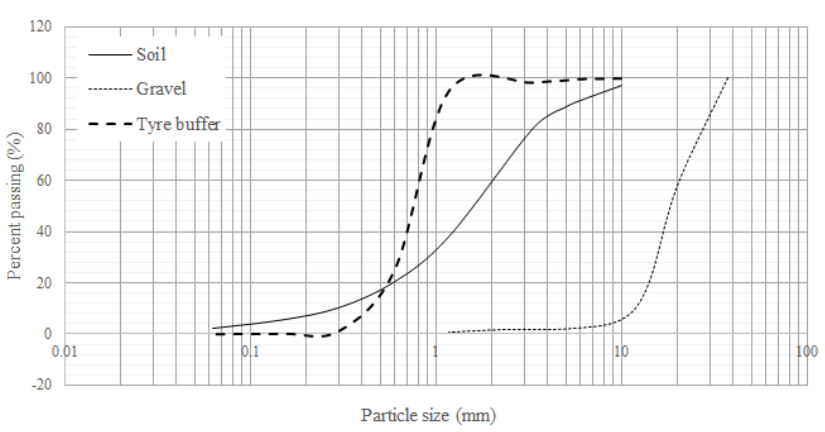

Fig 5. Particle size distribution of soil, gravel and tyre buffer

Table III: Results of laboratory test conducted on materials used in the study

\begin{tabular}{|c|c|c|c|}
\hline Basic properties & Soil & Gravel & Tyre buffer \\
\hline $\mathrm{D}_{10}$ & 0.30 & 12.00 & 0.45 \\
\hline $\mathrm{D}_{30}$ & 0.92 & 16.00 & 0.65 \\
\hline $\mathrm{D}_{60}$ & 2.00 & 22.00 & 0.82 \\
\hline Coefficient of uniformity, $\mathrm{C}_{\mathrm{u}}$ & 6.67 & 1.83 & 1.82 \\
\hline Coefficient of curvature, $\mathrm{C}_{\mathrm{c}}$ & 1.41 & 0.97 & 1.14 \\
\hline Maximum dry density, $\rho_{\max } \mathrm{g} / \mathrm{cm}^{3}$ & 1.6 & 1.63 & 1.465 \\
\hline Specific gravity, $\mathrm{G}_{\mathrm{s}}$ & 2.56 & 2.72 & 1.15 \\
\hline
\end{tabular}

B. Unprotected slope model subjected to artificial rainfall

Fig. 6 shows the displacement variations against time of unprotected slope subjected to artificial rainfall. It is found that slope with steeper angle $\left(60^{\circ}\right)$ displaced the most compared to the other angle. Table IV shows the maximum displacement for various slope angle. The displacement of slope with $60^{\circ}$ angle is also found to be drastically at approximately 150 seconds after the commencement of the rainfall test. Due to the maximum displacement recorded and the time taken for slope to move, slope with $60^{\circ}$ angle was taken as the critical slope that need to be applied with protective countermeasure.

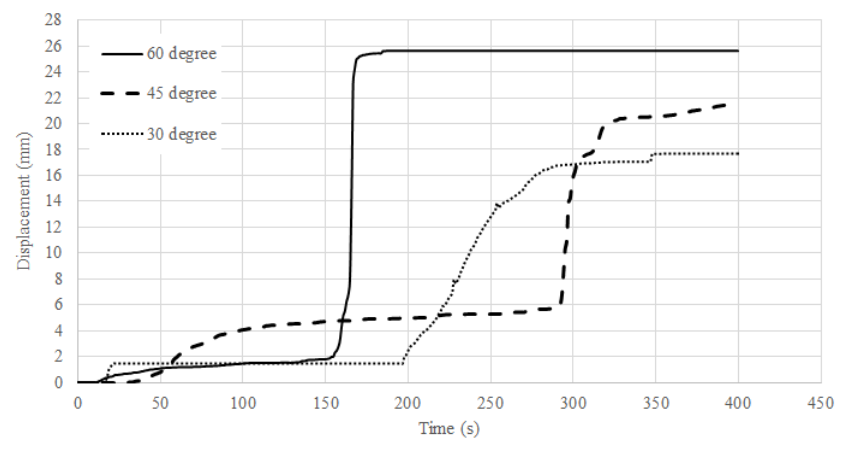

Fig 6. Displacement variations of unprotected slope with various angle

Table IV: Maximum displacement of unprotected slope with various angle

\begin{tabular}{|c|c|}
\hline Slope angle $\left(^{\circ}\right)$ & Maximum displacement (mm) \\
\hline 30 & 17.71 \\
\hline 45 & 21.65 \\
\hline 60 & 25.63 \\
\hline
\end{tabular}

\section{Protected slope model subjected to artificial rainfall (backfill made of TDGM)}

Fig. 7 shows the displacement variations against time experienced by protected slope model by using gabion wall made of gravel and tyre buffer mixture. All of these soil slope was protected by using gabion wall which was filled with various mixture of gravel and tyre buffer. The backfill material behind the gabion wall was using $100 \%$ of TDGM.

Table $\mathrm{V}$ shows the maximum displacement of gabion wall made from different proportion of gravel and tyre buffer mixture. It is found that, maximum displacement of gabion wall is significantly reduced from $25.63 \mathrm{~mm}$ (unprotected slope) to $1.62 \mathrm{~mm}$ (protected slope with gabion wall made of tyre buffer). Gabion wall filled with $100 \%$ gravel shows the best performance in protecting the soil slope where the maximum displacement recorded at the end of the test was only $0.08 \mathrm{~mm}$. In cases which using gravel and tyre buffer mixture, proportion of $80: 20$ is found to be the best ratio compared to other ratio.

Meanwhile, Fig. 8 shows the displacement variations against time experienced by protected slope model by using gabion wall made of gravel and tyre chip mixture. In comparison of two proportion of gravel and tyre chip mixture, proportion of 80:20 is found to be nearer to the performance of gabion wall made of purely gravel. Table VI shows the maximum displacement of gabion wall made from different proportion of gravel and tyre chip mixture. Laboratory model test for the case of gravel and tyre chips mixture of 20:80 and 0:100 are unable to be conducted due to limitation of tyre chips.

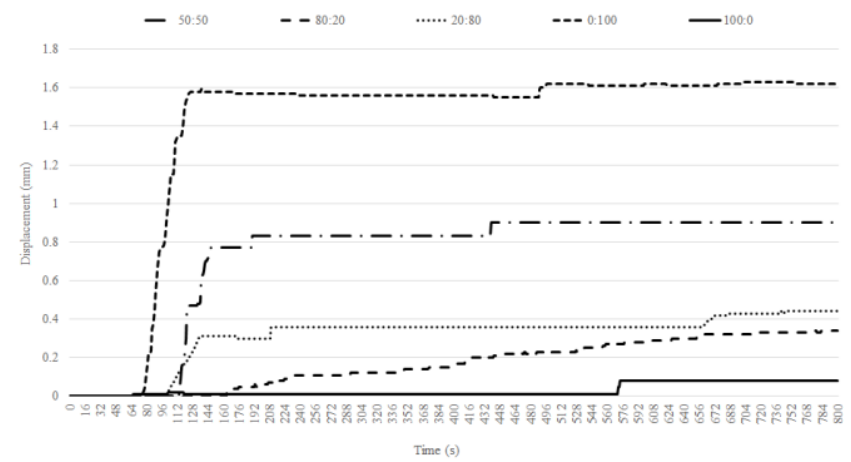

Fig 7. Variation displacement of slope model protected with gabion wall made from various proportion of gravel:tyre buffer mixture

Table V: Maximum displacement of protected slope with gabion wall made of gravel and tyre buffer mixture

\begin{tabular}{|c|c|}
\hline $\begin{array}{c}\text { Proportion of gravel and tyre } \\
\text { buffer mixture }\end{array}$ & Maximum displacement (mm) \\
\hline $100: 0$ & 0.08 \\
\hline $80: 20$ & 0.34 \\
\hline $50: 50$ & 0.44 \\
\hline $20: 80$ & 0.90 \\
\hline $0: 100$ & 1.62 \\
\hline
\end{tabular}




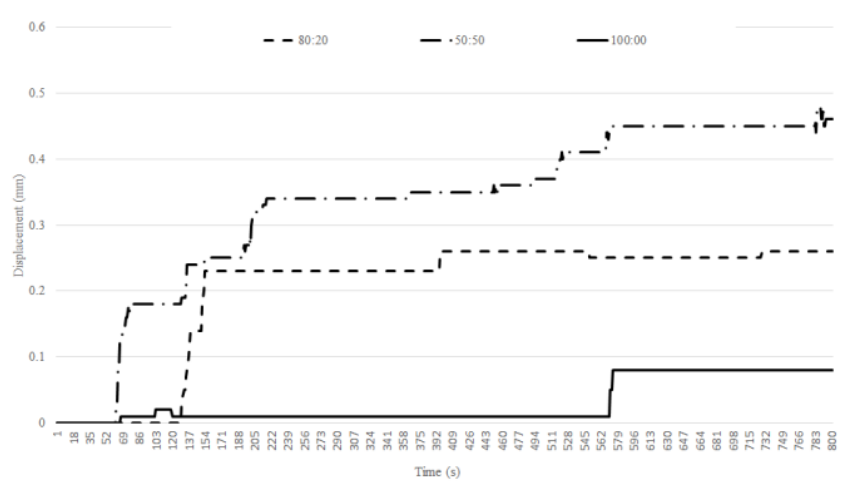

Fig 8. Variation displacement of slope model protected with gabion wall made from various proportion of gravel:tyre chips mixture

Table VI: Maximum displacement of protected slope with gabion wall made of gravel and tyre chip mixture

\begin{tabular}{|c|c|}
\hline $\begin{array}{c}\text { Proportion of gravel and tyre } \\
\text { buffer mixture }\end{array}$ & $\begin{array}{c}\text { Maximum displacement } \\
(\mathbf{m m})\end{array}$ \\
\hline $100: 0$ & 0.08 \\
\hline $80: 20$ & 0.26 \\
\hline $50: 50$ & 0.48 \\
\hline
\end{tabular}

From Fig. 7 and Fig. 8, it can be observed that there are significant movement of gabion wall made of either tyre buffer or tyre chip compare to gabion wall made of purely gravel. Utilization of larger amount of tyre buffer and tyre chips resulted to larger displacement of gabion wall. Larger displacement of gabion wall was due to the low density material that have been used. Lower density material (TDGM) was found to be unable to withstand overburden pressure (heavier soil due to saturation process) from the top of the slope.

\section{Protected slope model subjected to artificial rainfall (backfill made of various material)}

The lightweight properties of tyre derived geomaterial (either tyre buffer or tyre chip) resulted to significant displacement of the gabion wall. Therefore, in order to reduce the displacement, backfill material was changed from using only pure tyre derived material $(100 \%)$ to mixture of gravel and tyre derived material (by 50\% ratio). The replacement of backfill material to $100 \%$ gravel also has been conducted. Fig. 9 shows the displacement of gabion wall made of various material with various backfill material while Table VII highlights the effect of using various types of backfill material (in percentage form).

Based on the results, gravel is found to be the most suitable material to be used as backfill for gabion wall. The utilization of $100 \%$ gravel as the backfill material is able to reduce maximum displacement of the gabion wall (although that the result is still far compare to the conventional gabion wall). Gabion wall made of gravel and tyre chips mixture (ratio of $80: 20$ ) experienced $0.15 \mathrm{~mm}$ of displacement at the end of the test. Although that the percentage of difference is quite significant $(87.5 \%)$, the combination of this ratio with $100 \%$ gravel as the backfill material is the best condition compare to all cases.

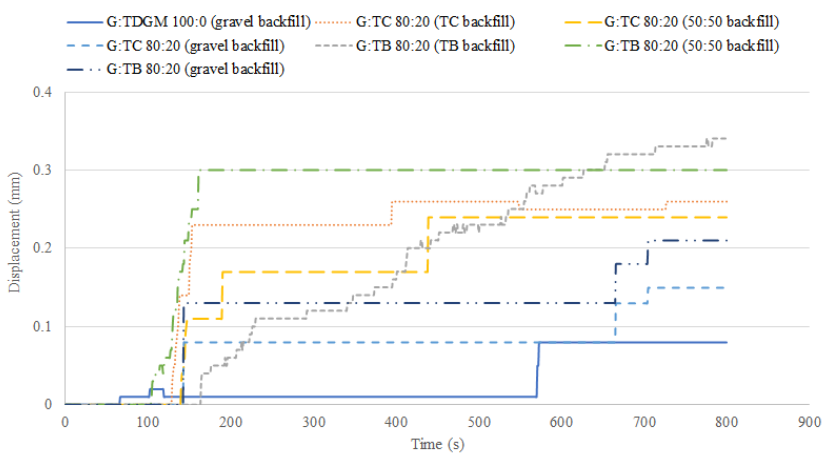

Fig 9. Displacement of gabion wall made of various material with various backfill material

Table VII: Effect of using various types of backfill material

\begin{tabular}{|c|c|c|c|}
\hline $\begin{array}{c}\text { Proportion } \\
\text { of gravel } \\
\text { and TDGM } \\
\text { mixture }\end{array}$ & $\begin{array}{c}\text { Proportion of } \\
\text { compacted } \\
\text { backfill } \\
\text { behind } \\
\text { gabion wall } \\
\end{array}$ & $\begin{array}{l}\text { Maximum } \\
\text { displacement } \\
(\mathbf{m m})\end{array}$ & $\begin{array}{c}\text { Percentage } \\
\text { of } \\
\text { difference } \\
(\%)\end{array}$ \\
\hline $\begin{array}{c}100: 0 \\
\text { Conventional } \\
\text { gabion }\end{array}$ & $\begin{array}{c}\text { Backfill : } 100 \% \\
\text { gravel }\end{array}$ & 0.08 & - \\
\hline \multirow{3}{*}{$\begin{array}{c}\text { 80:20 } \\
\text { (Gravel:tyre } \\
\text { buffer) }\end{array}$} & $\begin{array}{c}\text { Backfill : } 100 \% \\
\text { TDGM }\end{array}$ & 0.34 & -325 \\
\hline & $\begin{array}{c}\text { Backfill : } 50 \% \\
\text { TDGM }\end{array}$ & 0.30 & -275 \\
\hline & $\begin{array}{c}\text { Backfill : } 100 \% \\
\text { gravel }\end{array}$ & 0.21 & -162.5 \\
\hline \multirow{3}{*}{$\begin{array}{l}\text { 80:20 } \\
\text { (Gravel:tyre } \\
\text { chip) }\end{array}$} & $\begin{array}{c}\text { Backfill : } 100 \% \\
\text { TDGM }\end{array}$ & 0.26 & -225 \\
\hline & $\begin{array}{c}\text { Backfill : } 50 \% \\
\text { TDGM } \\
\end{array}$ & 0.24 & -200 \\
\hline & $\begin{array}{c}\text { Backfill : } 100 \% \\
\text { gravel }\end{array}$ & 0.15 & -87.5 \\
\hline
\end{tabular}

\section{CONCLUSION}

Tyre derived material is found to be less effective to be used as single material in replacing gravel as filler in gabion wall. High percentage of gravel still need to be added into the mixture of tyre material to ensure sufficient self-weight of the gabion. From this study, it is found that ratio of $80: 20$ (gravel:tyre) with $100 \%$ gravel backfill is the best compare to all ratio tested. However, the performance of gabion wall made of gravel and tyre mixture is still far compare to the performance of gabion wall made of purely gravel. Therefore, further study need to be conducted to reduce the amount of tyre material used in gabion wall. Finding other suitable material (other than tyre) or mixing tyre with additional material also can be another view that can be considered for this study in the future.

\section{ACKNOWLEDGMENT}

This work was supported by Universiti Malaysia Pahang under Grant of RDU1703305. Special thanks also goes to Hafiz Ashrawi, Ahmad Izzat Asyraf, Lim Li Yang and Mohd Ashraf for their effort in helping the research. 


\section{REFERENCES}

1. D. N. Humphrey, Tire derived aggregate as lightweight fill for embankments and retaining walls. Scrap Tire Derived Geomaterials Opportunities and Challenges - Hazarika \& Yasuhara (eds), Taylor \& Francis Group, London, 2008. pp. 59-81.

2. M. Garcia, M. A. Pando, and B. Tempest, "Tire derived aggregates as a sustainable recycled material for retaining wall backfills," Proc., International Conference on Sustainable Design and Construction 2011, Missouri, 2012, pp. 542-552.

3. D. Hartman, M. Ledezma, M. Xiao, and M. Zoghi, "Shake table test of MSE wall with tire derived aggregates (TDA) backfill," Geo-Congress 2013, United States, 2013, pp.1168-1177.

4. H. Tsang, "Seismic isolation by rubber-soil mixtures for developing countries," Earthquake Engineering and Structural Dynamics, 37, 2008, pp. 283-303.

5. D. S. Kim, K. Konagai, "Key parameters governing the performance of soft tunnel coating for seismic isolation," Earthquake Engineering and Structural Dynamics, 30(9), 2001, pp. 1333-1343.

6. A. Abdullah, and H. Hazarika, "The effectiveness of tire chip cushion as isolation layer under shallow foundation against dynamic loading," The $59^{\text {th }}$ Geotechnical Engineering Symposium, Nagano, Japan, 2014, pp. 559-562.

7. A. Abdullah, and H. Hazarika, "Improvement of shallow foundation using non-liquefiable recycle materials," Proc., $15^{\text {th }}$ Asian Regional Conference, 15ARC, Fukuoka, Japan, 2015, pp. 1863-1867.

8. A. Abdullah, and H. Hazarika, "The effectiveness of tire chips isolation layer beneath the foundation," The $11^{\text {th }}$ Environmental Geotechnical Engineering Symposium, Fukushima, Japan, 2015, CD-ROM.

9. A. Abdullah, and H. Hazarika, (2016). "Prediction of the soil liquefaction of an improved backfill -a numerical simulation-," Proc., $19^{\text {th }}$ Southeast Asian Geotechnical Conference \& the $2^{\text {nd }}$ AGSSEA Conference, 19SEAGC \& 2AGSSEA, Kuala Lumpur, Malaysia, 2016, pp. 281-284.

10. A. Abdullah, H. Hazarika, N. Yasufuku, and R. Ishikura, "Numerical study on seismic response of quay wall reinforced with tire chips," Proc., 14th International Conference of the International Association for Computer Methods and Advances Geomechanics, 14thIACMAG, Kyoto, Japan, 2014, pp. 1885-1889.

11. K. Yasuhara, H. Komine, S. Murakami, K. Taoka, Y. Ohtsuka, and T. Masuda, "Tire chips drain for mitigation of liquefaction and liquefaction-induced deformation in sand," Proceedings of Symposium on Technology of Using Artificial Geomaterials, Fukuoka, Japan, 2005 , pp. 115-118.

12. K. Fukutake, and S. Horiuchi, "Forming method of geostructure using recycled tires and granular materials," Proc., 41st Japan National Conference on Geotechnical Engineering, Kagoshima, Japan, 2006 , pp. 597-598 (in Japanese).

13. H. Hazarika, K. Yasuhara, Y. Kikuchi, A. K. Karmokar, and Y. Mitarai, "Multifaceted potentials of tire-derived three dimesional geosynthetics in geotechnical applications and their evaluation," Geotextiles and Geomembranes, 28(2010), 2010, pp. 303-315.

14. H. Hazarika, E. Kohama, and T. Sugano, "Underwater shake table tests on waterfront structures protected with tire chips cushion," Geotechnical and Geoenvironmental Engineering, 134 (12), 2008, pp. 1706-1719.

15. A. K. Karmokar, H. Takeichi, M. Kawaida, Y. Kato, H. Mogi, and K. Yasuhara, "Study on thermal insulation behavior of scrap tire materials for their use in cold region civil engineering applications," Proc., 60th Japan Society of Civil Engineers Annual Meeting, Tokyo, Japan, 2006, pp. 851-852.

16. Y. Kikuchi, T. Sato, T. Nagatome, T. Mitarai, and Y. Morikawa, "Change of failure mechanism of cement treated clay by adding tire chips," Proc., 4th Asian Regional Conference on Geosynthetics, Shanghai, 2008, pp. 374-379.

17. Public Works Department Malaysia - Slope Engineering Branch, Guidelines for slope design, JKR 21500-0011-10, 2010.

\section{AUTHORS PROFILE}

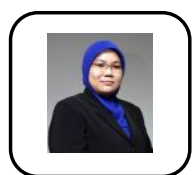

Amizatulhani Abdullah is currently a senior lecturer in Universiti Malaysia Pahang. She finished her tertiary level of education from Kyushu University (Ph.D) and Universiti Teknologi Malaysia (Master and Bachelor Degree). She is actively involved in research and had secured several internal as well as external research grant. Her field of expertise including but not limited to soil and geotechnical engineering. Her recent passion of research was utilizing waste materials in civil engineering field. She had published papers in recognized and indexed journals and her paper has been awarded as one of the best paper in The $2^{\text {nd }}$ International Symposium on Civil and Environmental Engineering (ISCEE18). She is also a member of Southeast Asia Geotechnical Engineering (SEAG) Society, a graduate member of Institution of Engineers Malaysia (IEM) and also a registered member of board of Engineers Malaysia (BEM).

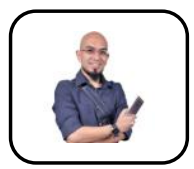

Dr. Haji Mohd Yuhyi Mohd Tadza received his bachelor's degree in Civil Engineering and master degree from Environmental, in USM. Later he obtained his $\mathrm{PhD}$ in Geotechnical Engineering from Cardiff University, UK. $\mathrm{He}$ is an Associate Professor in Faculty of Civil Engineering Technology, UMP. Currently, he seconded to the Ministry of Higher Education and appointed as the Director of Industry Centre of Excellence (ICOE), focusing on Construction. He is also actively involved in various multidisciplinary research relating to geotechnical and geoenvironmental engineering. 